\title{
Analysis of the Impacts of Compensation on Job Satisfaction amongst Teachers: A Case Study of Lakes State Ministry of Education, South Sudan
}

\author{
Article by Gai Emmanuel Mabor \\ Ph.D. Management, Texila American University \\ E-mail:egmabor@gmail.com
}

\begin{abstract}
Compensation is a systematic approach to providing value to employees in exchange for work performed. Compensation may achieve several purposes assisting in recruitment, job performance, and job satisfaction. Wage and salary administration is concerned with designing and implementing total compensation package.

The purpose of this research was to ascertain the impacts of compensation on the job satisfaction of teachers in Lakes State. The problem of the study revolved around teachers' dissatisfaction with their compensation before and in the aftermath of the South Sudanese civil war which started in December 2013, whereby the economic situation deteriorated badly, this further exacerbated the already dire situation of civil servants of various government ministries both at national and at sub-national levels. The economic downturn affected people's livelihood as cost of goods which are basically imported from the neighboring East African Countries of Kenya and Uganda soured. As prices continue to increase daily, staff salaries remained fixed. The research question was: what are the impacts of all forms of compensation on job satisfaction of teachers in Lakes State?

The research was carried out in four schools within Rumbek Township and 42 teachers were reached out of the targeted population of 47 teachers. Purposive sampling was used to identify respondents and pretested questionnaires were shared with them. The resultant data was tabulated and analyzed.

The findings showed lack of appropriate compensation which is embodied in the three predictor indicators (remuneration, supportive organization factors, demographic factors) and has caused unprecedented level of dissatisfaction among teachers. The predictor variables work in tandem to achieve a better job satisfaction for teachers or otherwise.
\end{abstract}

Keywords: Compensation, Remuneration, job satisfaction, employee turnover, and employee wellness.

\section{Introduction}

Compensation is a systematic approach to providing value to employees in exchange for work performed. Compensation may achieve several purposes assisting in recruitment, job performance, and job satisfaction. Wage and salary administration is concerned with designing and implementing total compensation package.

Teachers are the employees of the Ministry of Education through which learning is imparted. It should be noted that motivating employees by either monetary or other form is critical in the productivity of organizations. According the expectancy theory of motivation, employees exert more effort in anticipation of reward but in the case of teachers in Lakes State, there has been stalemate over the increment of teachers' salaries. Concerned education administrators never considered raising teachers' salaries to a minimum which is commensurate with the standard of living. This situation got worst in the aftermath of the crisis and the subsequent economic deep.

In the aftermath of the South Sudanese civil war which started in December 2013, the economic situation deteriorated badly, this further exacerbated the already dire situation of civil servants of various government ministries both at national and at sub-national levels. The economic downturn affected people's livelihood as cost of goods which are basically imported from the neighboring East African Countries of Kenya and Uganda soured. As prices continue to increase daily, staff salaries remained fixed. 
The purpose of this study is to ascertain the impacts of compensation on job satisfaction of teachers in Lakes State. The civil servants of the State Ministry of Education were surveyed as they had a long history of low salaries as compared to the other civil servants in other government institutions.

\section{Problem of the study}

Paying teachers' salaries commensurate with their workload and cost of living has been a common point of controversy in South Sudan even before and post-independence of the Country. Teachers complained every year of the low payment which cannot meet their monthly consumption requirements. As a result, teaching and pedagogy continued to be at stake because of dissatisfied workers in the ministry of Education. Professionals who were trained as teachers discarded their profession and went into the army, police service, and other well-paying jobs within the government, private sector, and non-governmental organizations.

The population of people aged 6 years who can read and write in Lakes State is 21 percent whereas majority of 79 percent cannot read and write while literacy level amongst people of 15 years is 18 percent and majority of 82 percent are illiterate (NBS, 2010). This can really portray the level of effort needed in Lakes State in the area of basic education for the young people. Lakes State is wrought into cyclical communal violence amongst the massive illiterate youth and having many children out of school reinforces the cycle of violence well into the future.

\section{Study question}

The main study question in this research is: what are the impacts of all forms of compensation on job satisfaction of teachers in Lakes State?

\section{Literature review}

The literal meaning of compensation is to counter-balance the reward and deliverables provided by the employee, in the context of human resource management, compensation is referred to as money and other benefits received by an employee for providing services to his employer. Money and benefits received may be in different forms, which may be associated with employee's service to the employer like the provident fund, gratuity, and insurance scheme (Mohanta, 2013)

\section{Job satisfaction and turnover}

The feeling of not being paid fairly in relation to workload has a negative impact on motivation, employees unhappy with levels of pay are more inclined to change jobs than employees who feel their salary was fair (Eurowork, 2013). Expectation in pay rise is likely to make employee work harder to realize the increment. Job satisfaction is closely related to the gratification of needs. It is composed of effective, cognitive and behavioral elements. These elements vary in their intensity and consistency from one individual to another. Thus, job satisfaction is the satisfaction derived from any pursuit directed by the process of fulfillment of the needs. It is the favorableness or un-favorableness with which employees view their work. It results from specific attitudes of employees in three areas viz., specific job factor, individual adjustment on the job and group relationship.

Several researches documented the threats to teachers' motivation, for instance, Save the children's study of this subject matter in developing Countries identified eight inter-connected areas as workload challenges, remuneration, recognition and prestige, accountability, career development, institutional environment, voice, and lack of teaching and learning materials (Guajardo, 2011). According to Muguongo, Muguna, and Muriithi (2015), the issue of compensation has led to many stand offs between teachers' union and the government of Kenya where teachers have often 'downed their tools' to compel the government to heed to their bargain.

According to Alyaha, D.O., Mbogo, R.W. (2017) in a study of working condition of teachers in Yei, South Sudan, massive number of job turnover was recorded by the County department of education as teachers quit their profession, such transfer is attributable to poor working conditions of teachers including low remuneration, delayed salaries, lack of tools (teaching and learning materials), and lack of other benefits. 
Another case study in Juba, South Sudan revealed a severe shortage of qualified teachers at all levels of the learning continuum. the movement of teachers out of the teaching profession could be attributed to the fact that, working environments in schools are no longer friendly to teachers: salaries are low, training opportunities are rare and teaching is being viewed as a profession of low income and prestige. Moreover, it is apparent in most South Sudanese urban secondary schools that class sizes are large, teaching workload is huge and unrewarded, cost of living is high, accommodation for teachers is problematic, professional development programs are unheard of, and cases of physical insecurity in remote rural area schools are prevalent (Ajak, 2015).

\section{Pay practice}

Payment of government civil servants has been irregular since the outbreak of the South Sudanese Civil War in December 2013. Teachers have stayed for several months without their salaries. This further worsened the already dire situation as they cannot afford to feed their families and meet essential commodities. Subsequently various fraternities including teachers at all levels, doctors, and lawyers downed their tools to pressure the government to heed their call for salary increment and prompt payment by the end of each month as well as payment of the arrears (Oluoch, 2016).

Other researches showed positive correlation between payment and job satisfaction; Mudor and Tooksoon (2011) argued that higher pay attracts prospective employees to apply for a job during recruitment, it helps organization to retain high performing employees as well as enhancing employee performance when pay raise is based on good performance.

Pay practices comprised of many components such as fringe benefits which may not be necessarily reflected on the employee's pay slip at the end of the month, they include dependents' education, power generators, housing security, social club membership fees among others. Another important component of pay practice is pension scheme, such scheme is being implemented by government and other institutions in South Sudan but with problems at the time of compensation of a staff member. As a result of this flaw many elderly people who have reached retirement age are still being retained in service because of not proper retirement scheme.

\section{Job training}

Opportunities for training and development are major factors in decisions regarding peoples' careers. They are factors evaluated in the job hunting process by prospective employees, are cited in surveys as to why workers accept jobs with certain employers, and are noted as reasons why employees stay with an employer and why they leave one employer for another. In a study by Schmidt a positive correlation exists between job training satisfaction and overall employee satisfaction in customer/technical service positions. The significant of on-the-job training should not be over-emphasized as trained worker in highly technical job may decide to leave the organization which is a great loss to the organization in terms of training cost, sourcing and training of a new employee to fill the vacant post.

The context of South Sudan, teachers have had immense in-service training programs, most of which are funded by INGOs. However, due to incapacity of some teachers such as those who dropped-out at primary 8 and became teachers, it is utterly impossible to train them to become best quality teachers. As Alyaha, D.O., Mbogo, R.W. (2017) argued in their article, if working conditions are not conducive, hardworking employees who can find jobs elsewhere leave while mediocre employees would stay, this is especially true of those school dropouts who have no choice but remain as teachers and sadly unproductive teachers.

\section{Theoretical framework}

This research places employee satisfaction within intricate diverse variables. Employee satisfaction is a function of multifaceted internal and organizational factors, if all those factors are favorably achieved, employees will be satisfied and vice versa. 


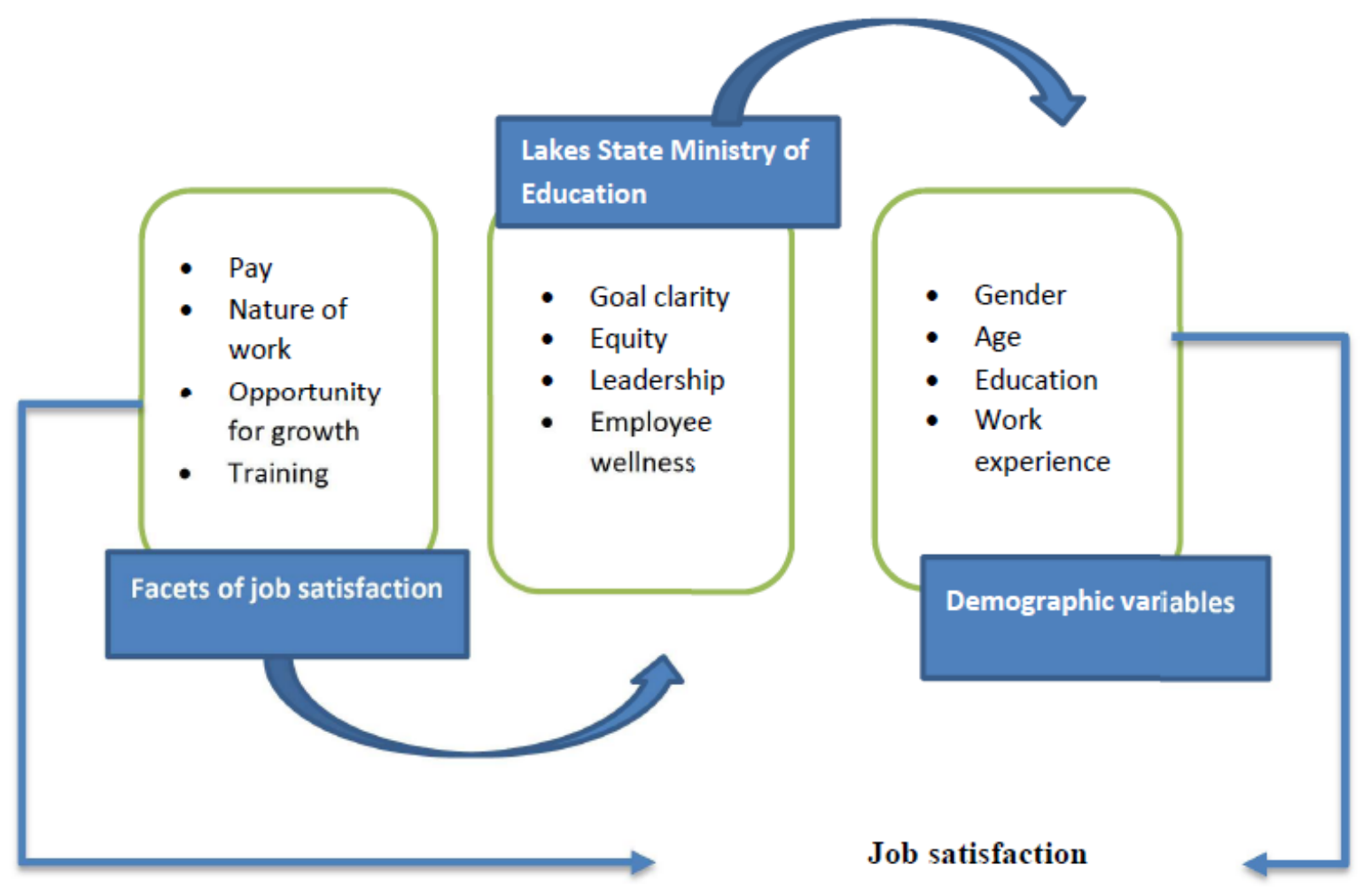

Figure 1. Conceptual framework

\section{Variables}

The research classified three comprehensive independent variables: the first being facets of job satisfaction. This variable contains many attributes which influence job satisfaction, they include: pay, nature of work, opportunity for growth, and training. It should be noted that there is no single attribute which can improve satisfaction without the other.

The second independent variable is the organization factors (factors with Lakes State Ministry of Education). Attributes within these are: organizational goal clarity which improvise performance and subsequent feeling fulfillment among employees, sense of equity among employees, supportive leadership, and pursuance of employee wellness schemes.

The third independent variable is demographic factors which comprise of gender, age, education, and work experience. Those attributes have influence on remuneration, promotion/retirement etc. All the three independent variables are interwoven and work in tandem to influence the dependent variable which is overall job satisfaction.

\section{Methodology}

\section{Research design and sampling techniques}

The study used both quantitative and qualitative research methods where a survey and key informant interviews were conducted in four primary schools in Rumbek township reaching a total of 42 teachers, Head Teachers, and Inspectors. The respondents were purposively sampled as each of them had a unique role in schools and based on seniority as those in senior positions may have varying levels of motivation than others. The Head Teachers were selected because they are responsible for the general wellness and motivation of teachers at school level and could have a repository of matters relating to teachers' motivation. 5 Inspectors, 4 Head Teachers, 8 Senior Teachers, and 25 Teachers responded to the survey as tabulated below. 
Table 1. Showing sample teachers and their respond rate

\begin{tabular}{|l|l|l|l|}
\hline S/N & Category of Teachers & Target Number & Response Rate \\
\hline 1 & Inspectors & 5 & 5 \\
\hline 2 & Head Teachers & 4 & 4 \\
\hline 3 & Senior Teachers & 8 & 8 \\
\hline 4 & Teachers & 30 & 25 \\
\hline & Total & $\mathbf{4 7}$ & $\mathbf{4 2}$ \\
\hline
\end{tabular}

Source: primary data

A total of 47 respondents were purposively identified in the four primary schools of Rumbek Girls' primary school, Riak-dor primary school, Ager-gum primary school, and Comboni primary school in Rumbek town. A response rate of 89 percent was achieved as some teachers could not return the questionnaires within the prescribed time. Nine key informant interviews were conducted with Head Teachers and Inspectors.

\section{Data collection instruments and procedures}

Questionnaire were developed for the research and pre-tested on a small sample of teachers in Rumbek Girls' primary school in Rumbek town. On considerations of the feedback, the questionnaire was finalized and distributed to respondents. Inspectors and Head Teachers were reached through a face-to-face key informant interviews and their consent was asked for the Investigator to take notes.

\section{Data analysis}

Triangulation of numerical and qualitative data was done as data trickle in from the respondents. The data was grouped by question and presented in excel. Data analysis was carried out to reach the deductions presented in the following sections.

\section{Results}

Table 2. Determination of how remuneration and pay influence teachers' satisfaction

\begin{tabular}{|l|l|l|l|l|l|l|l|l|}
\hline Statement & SA & $\%$ & A & $\%$ & D & $\%$ & SD & $\%$ \\
\hline My salary is adequate and regular & 0 & 0 & 0 & 0 & 0 & 0 & 42 & 100 \\
\hline My salary can meet the cost of living & 0 & 0 & 0 & 0 & 0 & 0 & 42 & 100 \\
\hline $\begin{array}{l}\text { In the last 5 years, my salary has } \\
\text { increased }\end{array}$ & 0 & 0 & 4 & 9.5 & 0 & 0 & 38 & 90.5 \\
\hline
\end{tabular}

Source: Primary data

On a continuum of strongly agreed to strongly disagreed, when the participants were asked, all the 42 respondents indicated that their salaries were not satisfactory to them. They further reported that their salaries do not meet the rising cost of living in the Country. A small number of respondents, only 4 of them reported that their salaries has increased by some margin as a result of incentivization of salary allowances by the European Union. However, majority, 38 of them reported never that they benefited from the salary incentive and thus did not realized any salary increment.

Table 3. Responses to nature of work, opportunity for growth, and training

\begin{tabular}{|l|l|l|l|l|l|l|l|l|}
\hline Statement & SA & $\%$ & A & $\%$ & D & $\%$ & SD & $\%$ \\
\hline I attended in-service training in the last 5 years & 21 & 50 & 0 & 0 & 21 & 50 & 0 & 0 \\
\hline I have been promoted in the last 5 years & 15 & 35.7 & 0 & 0 & 0 & 0 & 27 & 64.3 \\
\hline I have opportunity to grow in my organization & 2 & 4.8 & 5 & 11.9 & 10 & 23.8 & 25 & 59.5 \\
\hline I have the required tools to do my job & 0 & 0 & 0 & 0 & 12 & 28.6 & 30 & 71.4 \\
\hline
\end{tabular}

Source: Primary data 
ISSN: $2520-310 \mathrm{X}$

As depicted in the above table, almost half, 50\% of the respondents indicated having attended an inservice training while the remaining 50\% respondents did not attend in-service training for teachers. Majority of $64.3 \%$ respondents reported that they have not been promoted since their employment with Ministry of Education. About 15 respondents holding administrative function as either Senior Teachers, Head Teachers and Inspectors admitted having promoted at least once in the last 5 years of service. Lastly $28.6 \%$ respondents cited that they do not have the required tools to do their jobs effectively while a massive majority of $71.4 \%$ strongly showed lack of appropriate tools for their jobs.

Table 4. Responses to organizational supportive culture

\begin{tabular}{|l|l|l|l|l|l|l|l|l|}
\hline Statement & SA & $\%$ & A & $\%$ & D & $\%$ & SD & $\%$ \\
\hline $\begin{array}{l}\text { Lakes State Ministry of } \\
\text { Education gives me freedom to } \\
\text { do my job }\end{array}$ & 0 & 0 & 30 & 71.4 & 12 & 28.6 & 0 & 0 \\
\hline $\begin{array}{l}\text { The employee wellness program } \\
\text { is good }\end{array}$ & 0 & 0 & 0 & 0 & 0 & 0 & 42 & 100 \\
\hline $\begin{array}{l}\text { The leadership is supportive to } \\
\text { teachers }\end{array}$ & 0 & 0 & 11 & 26.2 & 0 & 0 & 31 & 73.8 \\
\hline $\begin{array}{l}\text { The work atmosphere is } \\
\text { conducive for me }\end{array}$ & 0 & 0 & 0 & 0 & 0 & 0 & 42 & 100 \\
\hline $\begin{array}{l}\text { I know my job and what is } \\
\text { expected of me as a teacher }\end{array}$ & 35 & 83.3 & 7 & 16.7 & 0 & 0 & 0 & 0 \\
\hline
\end{tabular}

Source: Primary data

Another aspect of job satisfaction asked was attributes within the organization culture which are capable of influencing job performance and satisfaction. About $71.4 \%$ of responses showed that employees have freedom to do their job and $28.6 \%$ responses showed to the contrary. All the respondents, $100 \%$ cited that there is no wellness program in Lakes State Ministry of Education. All the participants also indicated that the work atmosphere is not good, characterized by killing of teachers and targeting along ethnic lines. Lastly, 83.3\% respondents depicted that they know their job and what the organization expect from them, only $16.7 \%$ somewhat agreed but requiring clarifications from their principals their roles.

Table 5. Responses to demographic factors influencing performance

\begin{tabular}{|l|l|l|l|l|l|l|l|l|}
\hline Statement & SA & $\%$ & $\mathrm{~A}$ & $\%$ & $\mathrm{D}$ & $\%$ & $\mathrm{SD}$ & $\%$ \\
\hline $\begin{array}{l}\text { My level of education is } \\
\text { commensurate with the work I } \\
\text { do }\end{array}$ & 17 & 40.5 & 20 & 47.6 & 5 & 11.9 & 0 & 0 \\
\hline $\begin{array}{l}\text { I am not segregate on the } \\
\text { gender ground at work }\end{array}$ & 21 & 50 & 3 & 7.1 & 10 & 23.8 & 8 & 19.1 \\
\hline $\begin{array}{l}\text { I have minimum experience in } \\
\text { the teaching profession }\end{array}$ & 31 & 73.8 & 10 & 23.8 & 1 & 2.4 & 0 & 0 \\
\hline
\end{tabular}

Source: Primary data

The last variable studied was the demographics of respondents and how this influence performance and job satisfaction. On similar continuum, $40.5 \%$ responses showed employees with requisite education qualification for them to teach at their differing levels. About $47.6 \%$ have some qualification but require further training to be at par and $11.9 \%$ do not have sufficient qualification. Along gender lines, $50 \%$ think that there is no segregation on gender lines, majority however disagree, citing existence of gender discrimination in the teaching professions. Lastly majority of the respondents said they have minimum experience in the teaching profession. 


\section{Discussion}

\section{Effects of low remuneration}

From the responses during this research, all the respondents, cited the issue of low salaries, irregular salaries payment as well as failure by the government to increase the remuneration of teachers. Teachers have been ridiculed in Lakes State as they virtually cannot afford to meet their consumption requirement.

One of the teachers in his responses for instance state that we cannot feed ourselves with the meagre salary we receive as such a " 25 kilograms of floor has been named as ader-wuthath" a Dinka phrase meaning a teacher cannot afford to buy a mere 25 kilograms of floor. Our situation is further aggravated by failure of the government to pay salaries for the last 8 months and without sufficient explanation from the Ministry of Education.

This has exacerbated the rate of turnover of abled teachers who found jobs with NGOs and the private sector. Teachers who have no potentials and with poor education background or no qualification at all are left to be the ones teaching across Lakes State. Subsequently, education quality has deteriorated especially in science subjects and mathematics evidenced by poor performance in national examinations. Responses from few government salaried teachers echo the need to improve this vice in order for the Ministry to retain quality work force. Previous researches in South Sudan; Ajak (2015) and Alyaha, D.O., Mbogo, R.W. (2017) found similar circumstances.

\section{Nature of work, opportunity for growth, and training}

On-the-job training for teachers has been fairly available for teachers in Lakes State, this has been possible because of the massive support from the INGOs operating in the state. About 50 percent of respondents reported having attended an in-service training. Majority of respondents however have no hopes of promotion in their career as teachers. Much as training seems to be available, it cannot alone determine a meaningful level of satisfaction among teachers.

Majority of respondents, 71.4 percent reported serious lack of teaching and learning tools which are key in the delivery of the work. Failure of the government to provide essential tools like chalkboards, poor classrooms with most classes taking place under trees, and many other accessories for teachers hinder teachers from doing their job. The overall effect of that is demotivation of teachers which further make them available for any other job they can find. By very nature of teaching, a tedious job considering the appalling teacher-to-student ration in South Sudan, they demand fair payment equivalent to the work they do. Further responses revealed poor working environment where teachers are target along ethnic dimensions, some teachers have been killed as a result of revenge attacks. This jeopardizes proper deployment of teachers. Lastly, 59.5 percent cited lack of hope for any promotion in the future, some of them have worked in the industry for the last ten years with no pay raise.

\section{Supportive organizational factors}

From the respondents, other facets of the organizational environment such as the freedom for them to work were good, 71.4 percent think they have a free work related environment for the performance of their task however, some -28.6 percent think there is no such favorable organization environment if other important components like growth to senior position are not assured by the Ministry.

All the respondents indicated that there is no conducive atmosphere and employee wellness program. They justified their views on ground that the government program of pension, though practically monthly deductions are collected from the employees, these contributions are not paid to those who left the teaching fraternity, they went also to say elderly civil servants are still in-service because the pension program is not capable of retiring and maintaining them with their pension contributions. These are serious demotivators for future oriented employees who want their pension contribution paid to them at the end of their service.

Lastly, the employees also felt unsupported by Lakes State Ministry of Education's leadership. In the annual sate budgeting process, Ministry of education receive small portion of annual budget. Teachers have been the most affected in the budget making process and the argument of the law makers 
has been the work force of the Ministry especially teachers is high. This leaves them hopeless as people representing them cannot get an adequate resolution to the impasse of low salaries.

\section{Demographic factors influencing performance}

The last predictor variable under demographic characteristics showed that 73.8 percent of the respondent possessed at least minimum skills in the teaching profession, also some of them consider themselves qualified for the teaching job. The issue of gender equality featured as major issue as female teachers are very few in schools. There is direct correlation between certain factors such as education level and remuneration under the South Sudan Public service regulation and most of the teachers are victim because of lack of education threshold for promotion and attainment of higher grades.

\section{Conclusion}

In a nutshell, the purpose of this research was to ascertain the impacts of compensation on the job satisfaction of teachers in Lakes State. The research was carried out in four schools of Rumbek Girls' Primary School, Ager-gum Primary School, Riak-dor Primary School, and Comboni Primary School within Rumbek Township and 42 teachers were reached out of the targeted population of 47 teachers. The resultant data was tabulated and analyzed.

The findings showed lack of appropriate compensation which is embodied in the three predictor indicators (remuneration, supportive organization factors, demographic factors) and has caused unprecedented level of dissatisfaction among teachers. The predictor variables work in tandem to achieve a better job satisfaction for teachers or otherwise. Teachers are dissatisfied with their jobs because of low remuneration, poor supportive organizational and general environment and inadequacy of tools at their disposal to do work.

\section{Recommendations}

The following recommendations were reached during this research

1. Government of Lakes State must review the remuneration of teachers and propose salaries which are commensurate with the work and cost of living.

2. There is need for at least extended training other than the short courses being offered by the INGOs.

3. Lobby for increment of budget allocation for Ministry of education by Ministry Leaders and even civil society.

4. Revamp the pension scheme and other wellness programs like medical insurance

\section{References}

[1]. Ajak, Mading, M. (2015). The Root Causes of Teacher Attrition (Teacher Dropout) in the Conflict Affected South Sudan, Central Equatorial State: Case Study of Garang Memorial schools.

[2]. Mohanta Dr., G.C (2013). Concept of compensation and reward, compensation dimensions, system of compensating. Al-Qurmoshi Institute of Business Management, Hyderabad.

[3]. European Observatory of Working Life (2013). Impact of salary on job satisfaction. https://www.eurofound.europa.eu/observatories/eurwork/articles/impact-of-salary-on-job-satisfaction accessed on 3rd Nov. 2017

[4]. East African Newspaper URL: http://www.theeastafrican.co.ke/news/South-Sudan-facing-unrest-overdelayed-salaries--/2558-3267300-36i90t/index.html accessed on 12 Nov. 2017.

[5]. Guajardo, Jarred (2011). Teacher Motivation: Theoretical Framework, Situation Analysis of Save the Children Country Offices, and Recommended Strategies. https://www.oxfamnovib.nl/Redactie/Downloads/English/SPEF/281-

24\%20Teacher\%20Motivation\%20Report.pdf accessed on $5^{\text {th }}$ Nov. 2017.

[6]. Kenya. Journal of Human Resource Management Volume 3, Issue 6, December 2015, Pages: 47-59.

[7]. Muguongo, Mary Makena; Muguna, Andrew T.; Muriithi, Dennis K. (2015). Effects of Compensation on Job Satisfaction among Secondary School Teachers in Maara Sub - County of Tharaka Nithi County.

[8]. National Bureau of Statistics (2010). Statistical Yearbook for Southern Sudan. Published by Southern Sudan Centre for Census, Statistics and Evaluation P.O. Box 137, Juba. 
[9]. Oluoch, Fred (2016). South Sudan facing unrest over delayed salaries. News Article Published in the Schmidt, Steven W. The Relationship between Satisfaction with on-the-job training and overall job satisfaction. 